\title{
Penentuan Status Mutu dan Beban Pencemaran Air Kali Dendeng Kota Kupang
}

Maria Magdalena Kolo ${ }^{\mathrm{a}}$

${ }^{a}$ Fakultas Pertanian, Universitas Timor, Kefamenanu, TTU - NTT, Indonesia, email:mariamagdalenachem89@gmail.com

Faculty of Agriculture, Timor University, Kefamenanu, TTU - NTT, Indonesia, email: mariamagdalenachem89@gmail.com

\section{Article Info}

\section{Article history:}

Received 4 Juni 2019

Received in revised form 19 Juni 2019

Accepted 27 Juni 2019

\section{DOI:}

https://doi.org/10.32938/slk.v2i1.712

Keywords:

beban pencemaran,

indeks pencemaran,

kali dendeng,

status mutu air

\section{Pendahuluan}

Air bersih sangat dibutuhkan oleh manusia untuk berbagai keperluan terutama untuk kebutuhan rumah tangga, keperluan industry maupun untuk keperluan pertanian dan lain sebagainya. Air yang digunakan untuk keperluan sehari-hari sebagian besar berasal dari sumber air tanah dan air sungai, oleh sebab itu kuantitas dan kualitas air sungai sebagai sumber air harus dipelihara.

Air menjadi masalah yang perlu mendapat perhatian yang serius dewasa. Air dapat menjadi malapetaka jika kualitas air telah mengalami penurunan dan kuantitas air sudah tidak mampu lagi memenuhi kebutuhan konsumsi manusia. Permasalahan ini disebabkan tercemarnya air oleh bermacam-macam limbah baik limbah padat, cair dan gas yang berasal dari berbagai kegiatan manusia seperti kegiatan industri maupun kegiatan lain yang berdampak terhadap menurunnya kualitas dan kuantitas air (Hartono B, 1988). Pemanfaatan air di Provinsi Nusa Tenggara Timur (NTT) umumnya untuk memenuhi berbagai keperluan, di antaranya sebagai sumber air bersih dan irigasi. Seiring dengan usaha peningkatan kesejahteraan masyarakat, perkembangan kawasan untuk berbagai pemenuhan kebutuhan juga meningkat dengan cepat. Perubahan penggunaan lahan akan berimplikasi pada perubahan kualitas sumber daya air.

Kali Dendeng merupakan salah satu kali yang berada di Kota Kupang Propinsi Nusa Tenggara Timur. Kali Dendeng merupakan induk dari tiga anak kali yaitu Kali Sembunyi, Kali Airnona dan Kali Bakunase. Air Kali Dendeng biasanya dimanfaatkan untuk berbagai jenis kebutuhan, termasuk untuk mensuplai air bersih bagi masyarakat Kota Kupang. Seiring dengan pesatnya perkembangan Kota Kupang berdampak pada terjadinya perubahan pengunaan lahan di sepanjang Kali Dendeng yang semula berupa kawasan hutan berubah menjadi kawasan pemukiman serta hilangnya jalur hijau. Perubahan tersebut berdampak pada kuantitas dan kualitas air Kali Dendeng(Djunaedi dkk, 2016).

Penurunan kualitas air kali disebabkan peningkatan jumlah penduduk disertai minimnya kesadaran masyarakat. Limbah yang dihasilkan setara dengan banyaknya jumlah penduduk yang bermukim di sepanjang kali Dendeng. Oleh karena itu, perlu dilakukan pengolahan kualitas mutu air dengan beberapa tahap seperti pencegahan, penanggulangan dan pemulihan air. Adapun beberapa metode telah digunakan untuk menilai status mutu air (Sahabuddin dkk, 2014) pada suatu sumber air yakni metode storet (Walukow, 2010) dan metode indeks pencemaran (Agustiningsih dkk, 2012). Berdasarkan uraian diatas, pada penelitian menentukan status mutu dan tingkat pencemaran air menggunakan metode Indeks pencemaran. Data yang dihasilkan pada metode ini akan dibandingkan dengan baku mutu kelas I. Analisis sampel ditentukan oleh beberapa parameter seperti $\mathrm{pH}$, suhu, $\mathrm{DO}, \mathrm{BOD}, \mathrm{COD}, \mathrm{NH}_{3}, \mathrm{NO}_{3}$ dan padatan tersuspensi, serta analisis beban pencemaran menggunakan parameter debit air, BOD, COD dan analisis padatan tersuspensi.

\section{Metode}

\section{a. Lokasi dan Teknik Pengambilan Sampel Air}

Sampel air diambil pada 5 stasiun (Kelurahan Mapoli, Kelurahan Air Nona dan Kelurahan Fontein) dari Kali Dendeng, dengan 2 kali penyamplingan dan 2 kali pengulangan dari masing-masing stasiun dengan selang waktu 2 minggu. Metode penentuan stasiun dilakukan dengan metode purposive sampling yaitu penentuan stasiun pengamatan dilakukan dengan memperhatikan berbagai pertimbangan dan kondisi daerah penelitian. Adapun teknik pengambilan sampel dalam penelitian ini adalah: sampel sesaat (grab sample), yaitu sampel yang diambil secara langsung dari badan air yang sedang dipantau

\section{b. Bahan dan alat}

Bahan- bahan yang digunakan dalam penelitian ini adalah: sampel air Kali Dendeng, akuades, serbuk $\mathrm{K}_{2} \mathrm{Cr}_{2} \mathrm{O}_{7}$ (p.a), $\mathrm{H}_{2} \mathrm{SO}_{4}$ pekat, $\mathrm{KH}_{2} \mathrm{PO}_{4}$ (merck), serbuk $\mathrm{Ag}_{2} \mathrm{SO}_{4}$ (merck), $\mathrm{MnSO}_{4} \cdot 2 \mathrm{H}_{2} \mathrm{O}$ (E-merck), $\mathrm{HgSO}_{4}$ (merck), $\mathrm{HgI}_{2}$ (merck), $\mathrm{NH}_{4} \mathrm{OH}$ (ar grade), $\mathrm{NaAsO}_{2}$ (merck), $\mathrm{H}_{3} \mathrm{BO}_{3}$ (merck), $\mathrm{Na}_{2} \mathrm{~B}_{4} \mathrm{O}_{7}, \mathrm{NaN}_{3}$ (merck), $\mathrm{KNO}_{3}, \mathrm{NH}_{4} \mathrm{Cl}$ (p.a), $\mathrm{ZnSO}_{4} .7 \mathrm{H}_{2} \mathrm{O}, \mathrm{KNaC}_{4} \mathrm{O}_{6} \cdot 4 \mathrm{H}_{2} \mathrm{O}, \mathrm{Na}_{2} \mathrm{~S}_{2} \mathrm{O}_{4} .5 \mathrm{H}_{2} \mathrm{O}$ (univar), $\mathrm{NaOH}$ (merck), $\mathrm{HCl}$ (merck), $\mathrm{Fe}\left(\mathrm{NH}_{4}\right)_{2}\left(\mathrm{SO}_{4}\right)_{2} \cdot 6 \mathrm{H}_{2} \mathrm{O}$ (merck), indikator feroin, fenantrolin (merck), $\mathrm{KNO}_{3}$ (merck), $\mathrm{KI}$ (uni lab), $\mathrm{MnSO}_{4}$ (merck), dan amilum (p.a).

Alat- alat yang digunakan dalam penelitian ini adalah: $\mathrm{pH}$ meter (A-211 pocket $\mathrm{pH}$ activon), spektrofotometer UV-Vis (HACHDR 2800), termometer, peralatan gelas, tabung inkubasi, desikator, pipet tetes, pipet volum, timbangan, neraca analitik (M-220D), kertas saring (Whatman 40), penjepit, seperangkat alat titrasi dan oven.

\section{c. Prosedur kerja}

Penelitian ini dilakukan dalam beberapa tahap yaitu survei lokasi, persiapan sampel dan analisis sampel. Adapun parameter yang langsung diukur di lapangan (insitu) yaitu $\mathrm{pH}$, suhu dan debit air, kemudian parameter-parameter yang dianalisis di laboratorium yaitu $\mathrm{DO}, \mathrm{BOD}, \mathrm{COD}, \mathrm{NO}_{3}, \mathrm{NH}_{3}$ dan padatan tersuspensi. Metode yang digunakan untuk analisis kualitas air berdasarkan APHA 2005.

\section{d. Analisis data}

Penentuan status mutu air menggunakan metode indeks pencemaran yang mengacu pada KepMen LH No. 115/2003, dengan menggunakan persamaan:

$$
P_{i j}=\sqrt{\frac{\left(\frac{C i}{L i j}\right)^{2} M+\left(\frac{C i}{L i j}\right)^{2} R}{2}}
$$

Dimana;

$\mathrm{L}_{\mathrm{ij}}=$ Kosentrasi parameter kualitas air yang dicantumkan dalam baku mutu peruntukan air $(\mathrm{J})$

$\mathrm{C}_{\mathrm{i}}=$ Kosentrasi parameter kualitas air di lapangan

$\mathrm{P}_{\mathrm{ij}}=$ Indeks pencemaran bagi peruntukan $(\mathrm{J})$

$\left(\mathrm{C}_{\mathrm{i}} / \mathrm{L}_{\mathrm{ij}}\right)_{\mathrm{M}}=$ Nilai, $\mathrm{C}_{\mathrm{i}} / \mathrm{L}_{\mathrm{ij}}$ maksimum

$\left(\mathrm{Ci} / \mathrm{L}_{\mathrm{ij}}\right)_{\mathrm{R}} \quad=$ Nilai, $\mathrm{C}_{\mathrm{i}} / \mathrm{L}_{\mathrm{ij}}$ rata-rata

Evaluasi terhadap nilai PI adalah:

$\begin{array}{ll}0 \leq \mathrm{P}_{\mathrm{ij}} \leq & \text { : memenuhi baku mutu (kondisi baik) } \\ 1,0<\mathrm{P}_{\mathrm{ij}} \leq 5 & \text { : cemar ringan } \\ 5,0 \leq \mathrm{P}_{\mathrm{ij}} \leq 10 & \text { : cemar sedang } \\ \mathrm{P}_{\mathrm{ij}}>10 & \text { : cemar berat }\end{array}$

\section{Hasil dan Pembahasan}

\subsection{Gambaran Umum Lokasi Penelitian}

Lokasi penelitian dilakukan pada Kali Dendeng yang termasuk wilayah administrasi Kota Kupang, Secara geografis berada pada koordinat

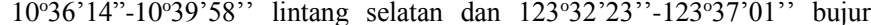
timur. Luas daerah aliran sungai sekitar $47,72 \mathrm{~km}^{2}$, dengan panjang kali 10,8 $\mathrm{km}$ dan terletak pada ketinggian 88-93 $\mathrm{m}$ di atas permukaan laut. Pengambilan sampel dilakukan pada 5 stasiun yaitu: stasiun I terletak di kelurahan Mapoli dan stasiun II terletak di kelurahan Airnona yang merupakan stasiun bagian hulu, kemudian stasiun bagian tengah yaitu stasiun III yang terletak sekitar 200 meter di atas bendungan dan stasiun IV yang terletak sekitar 200 meter di bawah bendungan, kemudian stasiun $\mathrm{V}$ yang merupakan stasiun bagian hilir terletak sekitar 1000 meter dari stasiun IV. 


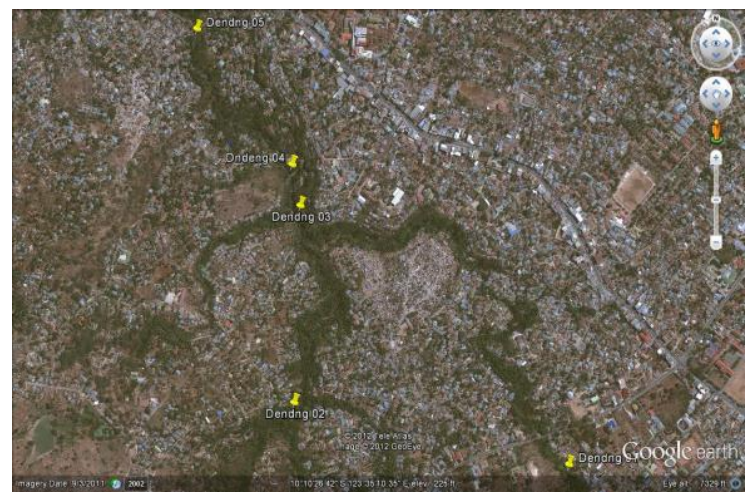

Gambar 1. Lokasi pengambilan sampel

\subsection{Parameter-parameter kualitas air}

\subsection{1 analisis suhu}

Suhu sangat penting dalam keberlangsungan proses biologi dan kimia di dalam air. Gambar 2 menunjukan hasil analisis suhu pada masingmasing stasiun untuk setiap pengambilan sampel pertama dan kedua. Ratarata suhu air untuk setiap stasiun yaitu stasiun I; $22{ }^{\circ} \mathrm{C}$, stasiun II; $23,5{ }^{\circ} \mathrm{C}$, stasiun III; $23^{\circ} \mathrm{C}$, stasiun IV; $22{ }^{\circ} \mathrm{C}$ dan stasiun V; $24^{\circ} \mathrm{C}$. Faktor yang mempengaruhi perbedaan suhu tersebut yaitu dilihat dari kedalaman badan air apabila semakin dalam badan air, suhu air semakin menurun. Kemudian faktor musim juga mempengaruhi suhu dimana cahaya matahari yang masuk ke perairan akan mengalami penyerapan dan perubahan menjadi energi panas.

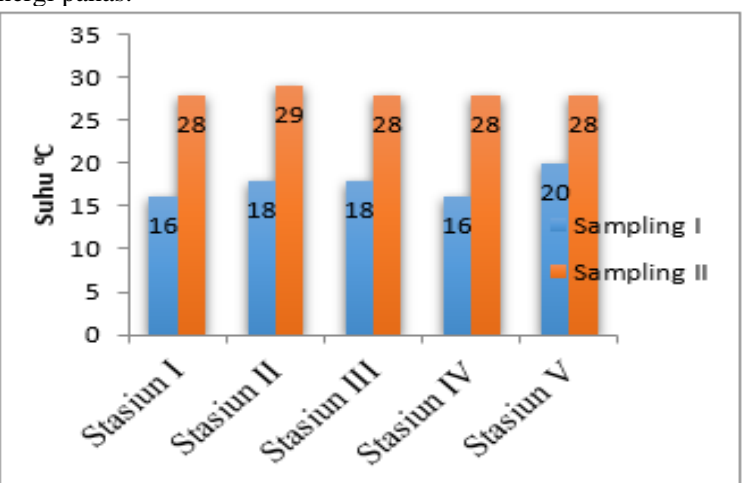

Gambar 2. Suhu air Kali Dendeng pada kelima stasiun pengukuran

Hasil penelitian menunjukkan rata-rata suhu udara dan suhu air Kali Dendeng pada stasiun I sampai stasiun $\mathrm{V}$ adalah $\pm 22,7^{\circ} \mathrm{C}$ dan $22,9{ }^{\circ} \mathrm{C}$. Berdasarkan PP No. 82 tahun 2001, standar suhu air yang diperbolehkan menurut baku mutu air kelas Iadalah deviasi 3 (Deviasi temperatur dari keadaan alamiahnya), maka rata-rata suhu air Kali Dendeng pada kelima stasiun tidak melampaui baku mutu yang ditetapkan.

\subsection{2 analisis ph}

Derajat keasaman atau $\mathrm{pH}$ merupakan konsentrasi ion hidrogen didalam air yang mencirikan keseimbangan asam dan basa. Nilai $\mathrm{pH}$ pada suatu perairan mempunyai pengaruh yang besar terhadap organisme perairan sehingga seringkali dijadikan petunjuk untuk menyatakan baik buruknya suatu perairan. Tingkat $\mathrm{pH}$ lebih kecil dari 4,8 dan lebih besar dari 9,2 maka air tersebut telah tercemar. Pengukuran $\mathrm{pH}$ pada lima stasiun air Kali Dendeng diperlihatkan pada Gambar 3.

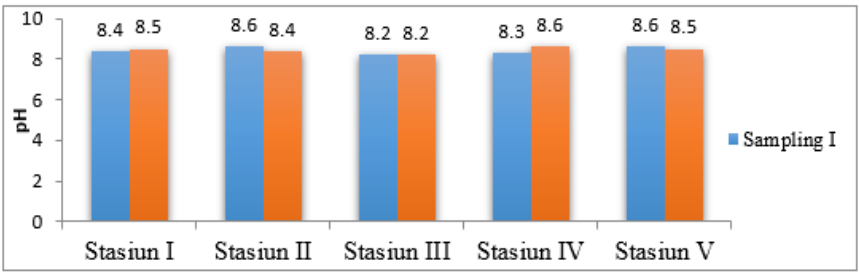

Gambar 3. pH air Kali Dendeng pada kelima stasiun pengukuran

Gambar 3 menunjukan nilai rata-rata $\mathrm{pH}$ pada stasiun I; 8,45, stasiun II; 8,5, stasiun III; 8,2, stasiun IV; 8,45 dan stasiun V; 8,55. Hal ini membuktikan bahwa kelima stasiun pengambilan sampel air tersebut memiliki nilai $\mathrm{pH}$ yang masih berada dalam ambang batas. Standar baku mutu air kelas satu menuru PP No 82 Tahun 2001, batas maksimum nilai pH adalah 6-9. Berdasarkan hasil analisis, rata-rata $\mathrm{pH}$ untuk kelima stasiun pengukuran tidak melampaui baku, sehingga air tersebut masih layak untuk digunakan sesuai peruntukkannya.

\subsubsection{Analisis Oksigen Terlarut(DO)}

Oksigen terlarut (DO) dalam air merupakan kebutuhan dasar untuk penunjang kehidupan di dalam air. Kehidupan organisme dalam air bergantung dari kemampuan air untuk mempertahankan konsentrasi oksigen minimal yang dibutuhkan untuk kehidupannya. Konsentrasi oksigen terlarut dalam keadaan jenuh bervariasi tergantung dari suhu dan tekanan atmosfer Konsentrasi oksigen terlarut yang terlalu rendah akan mengakibatkan ikan-ikan dan binatang lainnya yang membutuhkan oksigen akan mati. Sebaliknya konsentrasi oksigen terlarut yang terlalu tinggi juga mengakibatkan proses pengkaratan semakin cepat karena oksigen akan mengikat hidrogen yang melapisi permukaan logam (Astirin, dkk 2002). Hasil analisis DO pada air Kali Dendeng untuk analisis sampling pertama dan kedua ditampilkan pada Gambar 4.

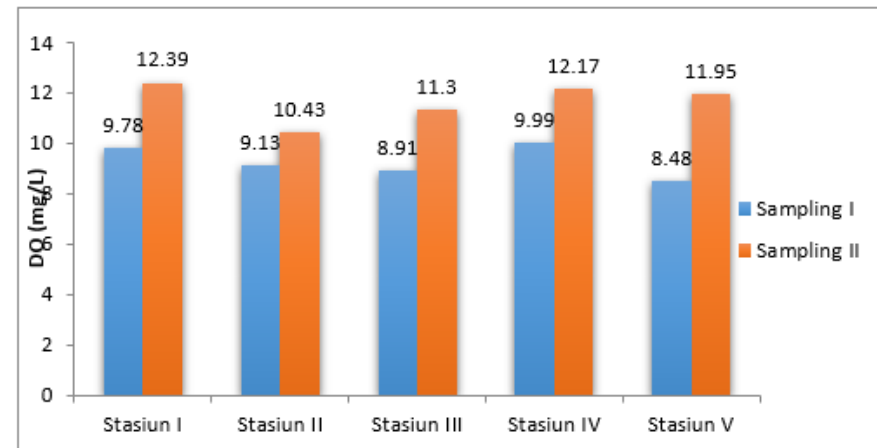

Gambar 4. DO air Kali Dendeng pada kelima stasiun pengukuran Gambar 4menunjukan rata-rata konsentrasi DO untuk kelima stasiun pengukuran. Rata-rata konsentrasi DO pada stasiun I; $11.08 \mathrm{mg} / \mathrm{L}$, stasiun II; 9,78 mg/L, stasiun III; $10.105 \mathrm{mg} / \mathrm{L}$, stasiun IV; $11,08 \mathrm{mg} / \mathrm{L}$ dan stasiun IV; $10,215 \mathrm{mg} / \mathrm{L}$. Berdasarkan standar baku mutu air kelas satu menurut PP No 82 Tahun 2001, batas minimum untuk nilai oksigen terlarut adalah $6 \mathrm{mg} / \mathrm{L}$. Dengan demikian nilai DO pada kelima stasiun pengambilan sampel air tersebut berada di atas standar baku mutu. Oleh karena itu Kali Dendeng masih dapat dimanfaatkan sesuai peruntukkannya.

3.2.4 analisis BOD

Hasil analisis rata-rata nilai konsentrasi BOD pada pengambilan sampe pertama dan kedua untuk kelima stasiun pengukuran.untuk stasiun I; 3,47 $\mathrm{mg} / \mathrm{L}$, stasiun II; 3,36 mg/L, stasiun III; 3,8 mg/L, stasiun IV; 3,80 mg/L dan stasiun $\mathrm{V} ; 4,45 \mathrm{mg} / \mathrm{L}$. Berdasarkan kandungan BOD yang terukur pada kelima stasiun untuk pengambilan sampel pertama maupun kedua jika dibandingkan dengan standar baku mutu air kelas 1 menurut PP No 82 Tahun 2001 (batas maksimum untuk nilai BOD adalah $2 \mathrm{mg} / \mathrm{L}$ ), dengan demikian kelima stasiun pengambilan air tersebut memiliki nilai BOD yang berada di atas standar baku mutu.

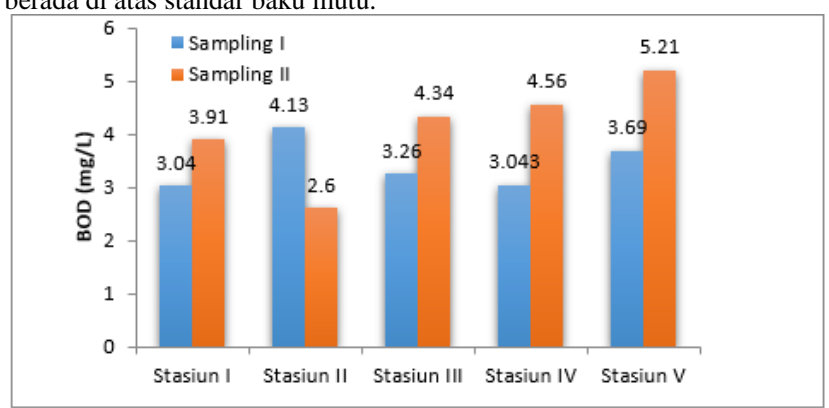

Gambar 5. Nilai BOD air Kali Dendeng pada kelima stasiun pengukuran

\subsection{5 analisis COD}

Konsentrasi COD rata-rata untuk tiap stasiun pada pengambilan sampel pertama dan pengambilan sampel kedua pada stasiun I; 47,6 mg/L, stasiun II; $70 \mathrm{mg} / \mathrm{L}$, stasiun III; 44,6 mg/L, stasiun IV; 87,2 mg/L dan stasiun V;

$71,8 \mathrm{mg} / \mathrm{L}$.

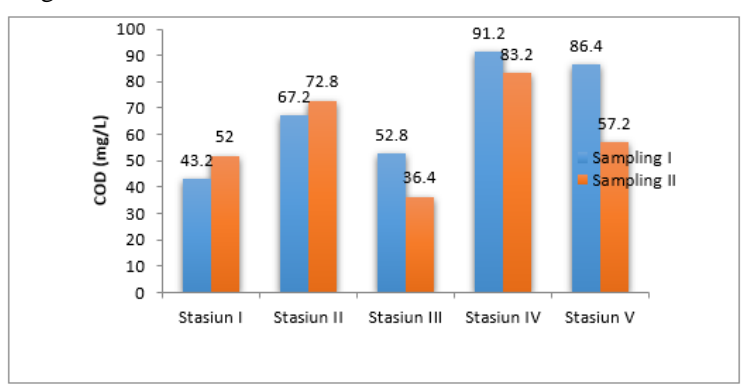

Gambar 6. Nilai COD air Kali Dendeng pada kelima stasiun pengukuran

Tingginya konsentrasi COD tersebut disebabkan karena banyak senyawasenyawa organik yang berasal dari sampah dan limbah penduduk yang dibuang ke badan air yang sulit teruarai sehingga membutuhkan zat-zat kimia untuk mengoksidasinya (Sasono, 2013). Berdasarkan baku mutu air kelas I kosentrasi 
COD yang diperbolehkan adalah 10 ppm (PP No. 82 tahun 2001), sehingga kelima stasiun pengambilan sampel tersebut sudah melampaui baku mutu air kelas I. Tingginya konsentrasi COD di atas dapat berpengaruh terhadap kelangsungan hidup organisme di dalam air dan dapat berpengaruh pada kesehatan manusia apabila air tersebut dikonsumsi.

3.2.6 analisis padatan tersuspensi (TSS)

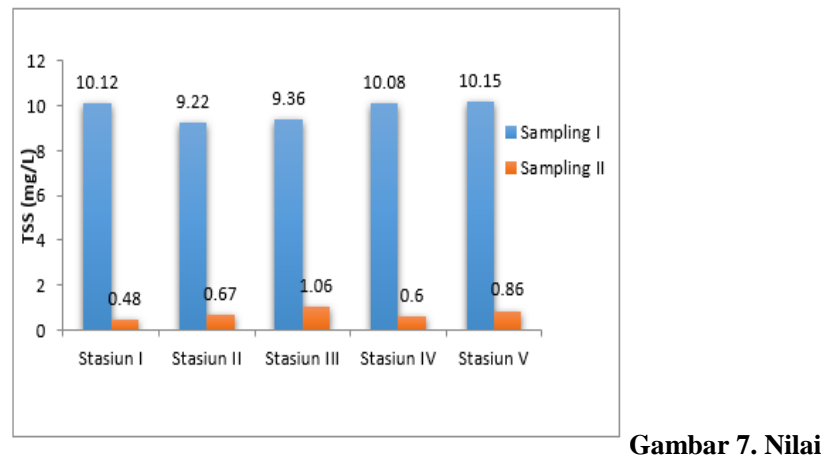

TSS air Kali Dendeng pada kelima stasiun pengukuran

Pada Gambar 7. terlihat bahwa konsentrasi padatan tersuspensi pada pengambilan sampel pertama lebih tinggi dibandingkan dengan pengambilan sampel kedua. Rata-rata konsentrasi TSS untuk setiap stasiun yaitu stasiun I; 5,3 $\mathrm{mg} / \mathrm{L}$, stasiun II; $4,94 \mathrm{mg} / \mathrm{L}$, stasiun III; $5,21 \mathrm{mg} / \mathrm{L}$, stasiun IV; $5,34 \mathrm{mg} / \mathrm{L}$ dan stasiun $\mathrm{V} ; 5,50 \mathrm{mg} / \mathrm{L}$. Pada pengambilan sampel pertama ini kondisi air sedikit keruh karena aliran air membawa partikel-partikel kecil seperti tanah liat ataupun bahan organik seperti pelapukan kayu dan tanaman tertentu yang masuk ke badan air dan juga kikisan tanah akibat hujan yang mempengaruhi jumlah TSS yang terukur tinggi. Kemudian pada saat pengambilan sampel kedua, kondisi air terlihat lebih jernih dibandingkan pada pengambilan sampel pertama karena aliran air tersebut hanya mengandung sedikit partikel-partikel kecil yang tidak larut sehingga padatan tersuspensi yang terukurpun lebih rendah.

Dalam Peraturan Pemerintah No.82 tahun 2001 telah ditetapkan standar baku mutu air kelas I untuk konsentrasi TSS adalah $50 \mathrm{mg} / \mathrm{L}$. Berdasarkan hasil analisis konsentrasi TSS pada kelima stasiun yang telah dilakukan, maka semua stasiun penyamplingan memenuhi baku mutu.

\subsection{7 analisis Nitrat $\left(\mathrm{NO}_{3}-\mathrm{N}\right)$}

Senyawa nitrat timbul secara alamiah dari proses penguraian dan pelapukan atau dekomposisi tumbuh-tumbuhan, sisa-sisa organisme yang telah mati dan buangan baik limbah dari kegiatan domestic, industri, pertanian maupun limbah peternakan (Mustofa A, 2015). Hasil analisis nitrat $\left(\mathrm{NO}_{3}-\mathrm{N}\right)$ sampling pertama dan kedua pada lima stasiun pengambilan sampel ditampilkan pada Gambar 8.

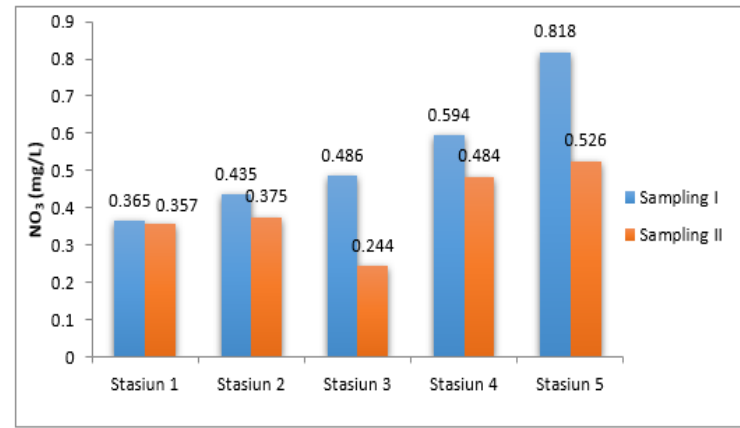

Gambar 8. $\mathrm{NO}_{3}$ air Kali Dendeng pada kelima stasiun pengukuran

Rata-rata konsentrasi nitrat untuk masing-masing stasiun yaitu stasiun I; $0,361 \mathrm{mg} / \mathrm{L}$, stasiun II; $0,405 \mathrm{mg} / \mathrm{L}$, stasiun III; $0,365 \mathrm{mg} / \mathrm{L}$, stasiun IV; 0,539 $\mathrm{mg} / \mathrm{L}$ dan stasiun V; $0,672 \mathrm{mg} / \mathrm{L}$. Dari Gambar 8 di atas terlihat bahwa konsentrasi nitrat semakin meningkat pada stasiun V. Hal ini disebabkan karena pada stasiun kelima terdapat rumah-rumah penduduk yang tinggal di sepanjang aliran air sehingga banyak sampah dan limbah buangan yang masuk ke badan air dan mengakibatkan konsentrasi nitrat juga meningkat. Berdasarkan PP No.82 tahun 2001 tentang baku mutu air untuk kelas I, kandungan nitratsebagai $\mathrm{N}$ yang diperbolehkan adalah $10 \mathrm{mg} / \mathrm{L}$. Kadar nitrat hasil analisis pada air Kali Dendeng tidak melampaui baku mutu. Akan tetapi kandungan nitrat yang ada akan membantu pertumbuhan alga, sehingga dapat menyebabkan oksigen dalam air dapat berkurang.

\subsection{8 analisis Amoniak (NH3-N)}

Amoniak dalam air permukaan berasal dari air seni, tinja serta oksidasi zat organik secara mikrobiologisyang berasaldari air alam atau air buangan industri dan penduduk. Sumber amoniak yang lain adalah reduksi gas nitrogen yang berasal dari proses difusi udara atmosfer (Widayat W, dkk 2010). Hasil analisis amoniak sampling pertama dan kedua pada air Kali Dendeng ditampilkan pada Gambar 9

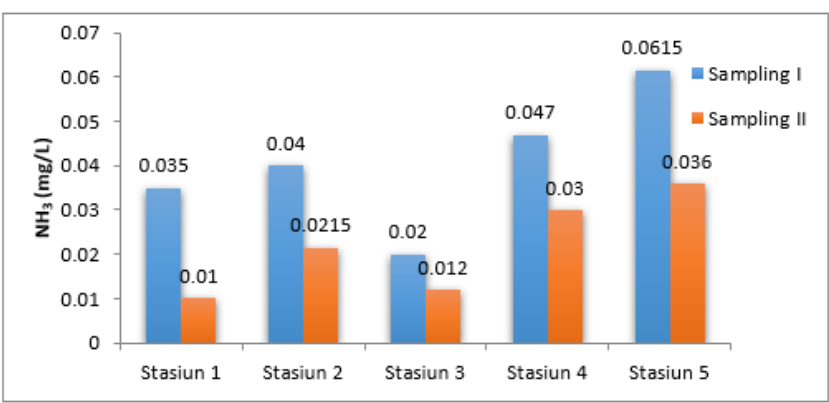

Gambar 9. $\mathrm{NH}_{3}$ air Kali Dendeng pada kelima stasiun pengukuran

Gambar 9 menunjukkan konsentrasi amoniak tiap stasiun pada pengambilan sampel pertama dan kedua. Rata-rata konsentrasi amoniak untuk masing-masing stasiun yaitu stasiun I; $0,022 \mathrm{mg} / \mathrm{L}$, stasiun II; $0,030 \mathrm{mg} / \mathrm{L}$ stasiun III; $0,016 \mathrm{mg} / \mathrm{L}$, stasiun IV; $0,038 \mathrm{mg} / \mathrm{L}$ dan stasiun $\mathrm{V} ; 0,048 \mathrm{mg} / \mathrm{L}$. Berdasarkan data pada Gambar 9, konsentrasi nitrat pada stasiun kelima lebih tinggi dibandingkan stasiun yang lain. Hal tersebut disebabkan banyak perumahan penduduk di sepanjang aliran air pada stasiun kelima sehingga banyak limbah yang dibuang ke badan air. Pada stasiun kelima ini banyak terdapat kandang ternak dan WC (jamban) yang pembuangannya dialirkan menuju badan sungai sehingga menimbulkan bau yang kurang sedap dan juga mempengaruhi konsentrasi amoniak meningkat.Berdasarkan peraturan pemerintah (PP) No.82 tahun 2001tentang baku mutu air kelas I kadar amoniak yang diperbolehkan adalah $0,5 \mathrm{mg} / \mathrm{L}$. Hasil analisis kadar amoniak pada kelima stasiun pengambilan air Kali Dendeng masih memenuhi baku mutu kelas I.

3.3 Hasil analisis status mutu air berdasarkan metode indeks pencemaran

Setelah dilakukan analisis kualitas terhadap air Kali Dendeng, maka diperoleh data kualitas air kali tersebut. Data kualitas air yang diperoleh selanjutnya dianalisis dengan menggunakan metode indeks pencemaran kemudian ditentukan status mutunya berdasarkan data indeks pencemaran. Penentuan status mutu ini dilakukan untuk mengetahui kondisi badan air Kali Dendeng secara keseluruhan dari stasiun satu sampai lima. Hasil pengukuran tingkat pencemaran air Kali Dendeng pada lima stasiun dengan menggunakan metode Indeks Pencemaran ditunjukkan pada Tabel 1.Berdasarkan data pada Tabel 1. disimpulkan bahwa air Kali Dendeng termasuk kategori cemar ringan menurut metode indeks pencemaran. Untuk lebih terperinci maka dapat dilihat data-data analisis indeks pencemaran dari masing-masing stasiun.

\section{Tabel 1. Hasil analisis Indeks Pencemaran}

\section{Stasiun Pij $\quad$ Evaluasi nilai}

\begin{tabular}{lll}
\hline I & 3,17817 & $1,0 \leq \mathrm{PIj} \leq 5,0$ \\
II & 3,78473 & $1,0 \leq \mathrm{PIj} \leq 5,0$ \\
III & 3,06235 & $1,0 \leq \mathrm{PIj} \leq 5,0$ \\
IV & 4,12400 & $1,0 \leq \mathrm{PIj} \leq 5,0$ \\
V & 3,80601 & $1,0 \leq \mathrm{PI} \mathrm{j} \leq 5,0$ \\
\hline
\end{tabular}

\subsection{Analisis beban pencemaran}

Analisis beban pencemaran dinyatakan dalam satuan jumlah beban pencemar per satuan waktu. Nilai beban pencemar dihitung dengan perkalian Antara konsentrasi dan debit air Kali Dendeng (Sembel, 2012). Analisis beban pencemaran ini bertujuan mengetahui jumlah suatu parameter pencemaran yang terkandung dalam air. Parameter-parameter yang dianalisis pada beban pencemaran yaitu BOD, COD dan TSS. Hasil analisis beban pencemaran tersebut kemudian dikonversi ke dalam ton/tahun. Pengukuran debit air dilakukan pada masing-masing stasiun pengambilan sampel dengan melihat kondisi dari permukaan air. Hasil analisis beban pencemaran untuk masing-masing stasiun dapat dilihat pada Tabel 2 .

Tabel 2. Analisis Beban Pencemaran Air Kali Dendeng

\begin{tabular}{lllll}
\hline Lokasi & Debit air & \multicolumn{3}{l}{ Beban pencemaran (Ton/tahun) } \\
\cline { 3 - 5 } & $\begin{array}{lllll}\left(\mathbf{m}^{3} / \text { det}\right) \\
n n n y y\end{array}$ & BOD & COD & TSS \\
\hline I & 1,165 & 126043,858 & 1724841,22 & 192296,242 \\
II & 0,644 & 52296,045 & 1403409,37 & 99311,261 \\
III & 3,110 & 368085,751 & 4315337,98 & 504463,977 \\
IV & 1,767 & 209110,304 & 4793012,93 & 293640,749 \\
V & 1,429 & 198172,835 & 3192857,45 & 245122,959 \\
\hline
\end{tabular}


Adanya beban pencemaran air Kali Dendeng yang tinggi ini disebabkan oleh sumber pencemar di sekitar kali yang memberikan kontribusi beban cemaran yang cukup tinggi terhadap badan air. Beban cemaran yang cukup tinggi ini juga merupakan salah satu indikasi adanya penurunan kualitas lingkungan di sekitar perairan kali. Adanya perubahan tata guna lahan pada daerah penyangga pada kali juga mengakibatkan beban cemaran meningkat. Suatu perairan memiliki kemampuan menampung beban pencemaran sampai pada batas-batas tertentu. Konsentrasi pencemar yang masuk ke perairan akan mengalami tiga fenomena yaitu pengen ceran, penyebaran dan reaksi penguraian. Proses-proses tersebut pada dasarnya merupakan sifat alamiah air yang memiliki kemampuan untuk membersihkan atau menghancurkan berbagai kontaminan dan pencemar yang dibawa oleh air limbah. Berdasarkan analisis beban pencemaran yang dilakukan dapat diketahui seberapa besar daya tampung dari perairan itu sendiri. Daya tampung beban pencemaran merupakan kemampuan air atau sumber air dalam menerima pencemaran tanpa memyebabkan terjadinya penurunan kualitas air yang ditetapkan sesuai peruntukannya. Daya tampung beban pencemaran dapat diketahui dari selisih antara beban pencemaran sesuai baku mutu terhadap beban pencemaran yang terukur. Untuk menghitung besar beban pencemaran sesuai baku mutu maka nilai atau standar baku mutu kelas I berdasarkan PP No. 82 tahun 2001 dikali dengan debit minimum dari pengukuran besar beban pencemaran yang diijinkan untuk parameter BOD, COD dan TSS dapat dilihat pada tabel 3 .

Tabel 3. Baku Mutu Beban Cemaran Pada Debit Minimum Kali Dendeng Untuk Kelas I Berdasarkan PP 82 tahun 2001.

\begin{tabular}{lll} 
Parameter & Debit (m3/s) & $\begin{array}{l}\text { Beban cemaran yang } \\
\text { diijinkan (ton/tahun) }\end{array}$ \\
\hline BOD & 0,64457 & 40097,4105 \\
COD & 0,64457 & 200487,0528 \\
TSS & 0,64457 & 1002435,264 \\
\hline
\end{tabular}

Berdasarkan hasil perhitungan debit maka air Kali Dendeng mengalami debit paling minimum pada stasiun II. Pada debit minimum ini beban cemaran yang ditanggung oleh Kali Dendeng akan semakin besar, karena semakin berkurangnya pengenceran limbah oleh air maka akan mengurangi daya tampung beban cemaran kali. Apabila konsentrasi BOD, COD dan TSS pada masingmasing stasiun tinggi maka daya tampung Kali Dendeng terhadap cemaran akan mengalami nilai minimum.

Ketika daya tampung Kali Dendeng mencapai nilai minimum maka dapa dilakukan upaya pengurangan terhadap cemaran dari sumber-sumber pencemar yang masuk ke badan air tersebut, dengan anggapan bahwa daya tampung merupakan fungsi debit. Semakin besar debit maka daya tampung akan semakin besar, sehingga apabila pada debit terkecil daya tampungnya memenuhi standar baku mutu, maka untuk debit yang semakin besar dengan sendirinya akan memenuhi standar baku mutu.

\section{Simpulan}

1. Hasil penelitian menunjukkan bahwa nilai rata-rata keseluruhan air Kali Dendeng untuk masing-masing parameter suhu, pH, DO, BOD, COD, TSS $\mathrm{N}-\mathrm{NO} 3$ dan N-NH3 secara berturut-turut yaitu: $22,9{ }^{\circ} \mathrm{C}, 8,43,10,45 \mathrm{mg} / \mathrm{L}$, $3,78 \mathrm{mg} / \mathrm{L}, 64,24 \mathrm{mg} / \mathrm{L}, 5,26 \mathrm{mg} / \mathrm{L}, 0,46 \mathrm{mg} / \mathrm{L}$ dan $0,03 \mathrm{mg} / \mathrm{L}$.

2. Status mutu air berdasarkan metode indeks pencemaran, Kali Dendeng dalam kondisi tercemar ringan dengan nilai indeks pencemaran berkisar dari 3,06235-4,12400 dengan nilai evaluasi PIj $1 \leq \mathrm{PIj} \geq 5$. Parameter yang berkontribusi terhadap tingginya nilai indeks pencemaran adalah BOD dan COD.

3. Beban pencemaran Kali Dendeng berdasarkan parameter BOD, COD dan TSS untuk masing-masing stasiun yaitu: Pada stasiun I dengan debit sebesar $1,1650 \mathrm{~m}^{3} / \mathrm{s}$ dapat menampung beban limbah untuk parameter BOD sekitar 126043,8589 ton/tahun, untuk parameter COD sekitar 1724841,216 ton/tahun dan untuk parameter TSS sekitar 192296,2421 ton/tahun. Pada stasiun II dengan debit sebesar $0,64457 \mathrm{~m}^{3} / \mathrm{s}$ dapat menampung limbah untuk parameter BOD sekitar 52296,04529 ton/tahun, utuk parameter COD sekitar 1403409,37 ton/tahun dan untuk parameter TSS sekitar 99311,2616 ton/tahun. Pada stasiun III dengan debit air sebesar $3,11074 \mathrm{~m}^{3} / \mathrm{s}$ dapat menampung limbah untuk parameter BOD sekitar 368085,7514 ton/tahun, untuk parameter COD sekitar 4315337,98 ton/tahun, dan untuk parameter TSS sebesar 504463,9775 ton/tahun. Pada stasiun IV dengan debit sebesar $1,76716 \mathrm{~m}^{3} / \mathrm{s}$ dapat menampung limbah parameter BOD sekitar 209110,3048 ton/tahun, untuk parameter COD sekitar 4793012,933 ton/tahun, dan untuk parameter TSS sekitar 293640,7493 ton/tahun. Kemudian untuk stasiun V dengan debit air sebesar $1,42968 \mathrm{~m}^{3} / \mathrm{s}$ dapat menampung beban limbah parameter BOD sekitar 198172,8354 ton/tahun, untuk parameter COD sekitar 3192857,451 ton/tahun dan untuk parameter TSS sekitar 245122,9594 ton/tahun.

\section{Pustaka}

Agustiningsih, D., Setia, B.S., Sudarmo. 2012. Analisis Kualitas Air Dan Strategi Penegendalian Pencemaran Air Sungai Blukar Kabupaten Kendal. Jurnal PRESIPITASI: Vol. 9 No. 2, ISSN 1907-187X

Astirin, O. P., Ahmad, D. S., Marti, H. 2002. Keragaman Plankton sebagai Indikator Kualitas Sungai di Kota Surakarta. BIODIVERSITAS: Vol. 3, No. 2, Juli 2001, hal. 236-241

Djunaedi., Joko, S., Albert Aun, U.N. 2016. Analisis upaya penanggulanagan debit limpasan permukaan (runn of) di sungai dendeng pada DAS Dendeng Kota Kupang Provinsi Nusa Tenggara Timur. Jurnal Teknik Sipil: Vol 1 nomor 2

Hartono, B. 1988. Review on water pollution studies in Indonesia. National Institute Of Health Research and Development. Jakarta. Buletin Penelitian Kesehatan 16 (2)

Mustofa, A. 2015. Kandungan Nitrat dan Pospat sebahgai Faktor Tingkat Kesuburan Perairan Pantai. Jurnal DISPROTEK: Vol. 6, No. 1, Januari

Sahabuddin, H., Donny, H., Emma, Y. 2014. Analisa Status Mutu Air Dan Daya Tampung Beban Pencemaran Sungai Wanggu Kota Kendari. Jurnal Teknik Pengairan, Volume 5, Nomor 1, Mei 2014, hlm 19-28

Sasono, E., Pungut. 2013. Penurunan Kadar BOD dan COD Air Limbah UPT Puskesmas Janti Kota Malang dengan Metode Contructed Wetland. Jurnal Teknik Waktu: Vol. 11 No. 01, Januari 2013, ISSN: 1412-186

Sembel, L. 2012. Analisis Beban Pencemar dan Kapasitas Asimilasi di Estuari Sungai Belau Teluk Lampung. Maspari Journal, 2012, 4 (2), 178-183

Walukow, A.F. 2010. Penentuan Status Mutu Air dengan Metode Storet di Danau Sentani Jayapura Propinsi Papua. Berita Biologi 10 (3)

Widayat, W., Suprihatin., Herlambang, A. 2010. Penyisihan Amoniak dalam Upaya Meningkatkan Kualitas Air Baku PDAM-IPA Bojong Renged dengan Proses Biofiltrasi Menggunakan Media Plastik Tipe Sarang Tawon. JAI: Vol. 6, No. 1 